\title{
The Voice of the Teacher in Syllabus Design
}

\author{
Fatimah Al-Kathiri ${ }^{1}$ \\ ${ }^{1}$ Curriculum and Instruction Department, King Saud University, Riyadh, Saudi Arabia \\ Correspondence: Fatimah Al-Kathiri, Curriculum and Instruction Department, King Saud University, Riyadh, \\ Saudi Arabia. E-mail: fatimakathiri@gmail.com
}

$\begin{aligned} & \text { Received: December 27, } 2015 \\ & \text { Accepted: January 18, } 2016 \quad \text { Online Published: February 26, } 2016 \\ & \text { doi:10.5539/ells.v6n1p87 }\end{aligned}$ URL: http://dx.doi.org/10.5539/ells.v6n1p87

\begin{abstract}
If curriculum is to reflect the goals of a nation and the needs of its students, it makes sense for teachers to participate in its creation. In fact, curriculum design has long been associated with the idea of teacher contribution. Thepresent effort tries to prove that Saudi EFL teachers can be active participantsrather than passive recipients. They can convey vital information to curriculum designers instead of being blindly subjected to ahighly centralized educational system. The study also provides a consideration of role requirements and the competencies of teachers as curriculum leaders. The data collected from semi-structured interviews indicate that teachersareneither involvednor informed in the process ofcurriculum design and that theirengagement is merelywithin their own classrooms walls. Although they play a central role in the process of education, yet they miss the passion of belongingas little attention, if any, is given totheir voices.
\end{abstract}

Keywords: Saudi EFL teachers, curriculum design, centralized educational system

\section{Introduction}

\subsection{Background}

No nation can develop or rise without the efforts of its teachers. They are considered one of the main pillars of a sound and progressive society. They bear the weight and responsibility of teaching, and, apart from parents, are the main source of knowledge and values for children. The importance of a teacher as an architect of our future generations demands that only the best and the most competent onesare allowed to beengaged in this noble profession. Without qualified, motivated and skillful teachers, the goal of education would be hard to achieve.

Today, teachers obtain more importance not merely in teaching but also in the art of designing and developingcurriculum. They are, in fact, an integral part of the decision-making process in curriculum planning and implementation at the classroom level. They can supplement and improve the curriculum through planning and working with students, engaging in professional development, and sharing their classroom experiences with other teachers (Doll, 1996). They can also be powerful positive forces for change ifthey are given the resources and support which will enable them to carry out syllabus implementation effectively (Kennedy, 1996). As Klein (1999) argued, "Teachers have the real power to make or break decisions advocated at any level. Their decisions will ultimately determine the curriculum, regardless of all other levels of decision making".

\subsection{Statement of the Problem}

In Saudi Arabia, however, syllabus design is the prerogative of a very centralized educational system in which teachers are hardly given any role (Al-Sadan, 2000). In return, they seem to miss the passion of belonging as they are not included in decision making. Therefore, the ultimate effect is on pupils. But in spite of this fact, their contribution inimplementation and application seems to play a fundamental role.

\subsection{Research Questions}

The issue of teacher's contributionin syllabus design raises many questions. The main ones that are to be discussed in this paper:

1) What is the general perception held by Saudi EFL teachers towards their role in syllabus design?

2) To which degree of freedom do they teach their syllabuses?

3) What qualifications do they possess to participate in the processes of syllabus design, implementation and evaluation? 


\section{Review of Literature Review}

Research on teacher participation in curricular decision-making focuses heavily on three dimensions; teacher involvement, whether real or perceived, the tendencies of educational systems towards teacher participation and the associated competencies of curriculum leaders.

\subsection{The Perception of Teacher Involvement}

Much of the work on this subject makes clear that teacher involvement does not lead to active engagement or successful curricular change (Bowers, 1991). It merely focuses on the engagement of teachers in the determination of curriculum within their own classrooms. Kennedy (1996) found that a general perception often held by teachers was that "the curriculum is developed else where" so that they simply need some guidance for the "correct application" of a curriculum which is "handed down to them from the top". They believe that the policy of decision making is highly centralized and that their engagement in the syllabus determination is within their own classroom practicesonly. Hecht, Higgerson, Gmelchand, \& Tucker (1999) indicated that this view had created the impression that teachers operate solely within the classroom wallsand that it was the only place where they could make a contribution to the curriculum denying the broader functions that couldpossibly be fulfilled outside the classroom.

Curriculum development as a concept is regarded as the encompassing and continual process during which any form of planning, designing, dissemination, implementation and assessment of curricula may take place (Carl, 2002). It is within this process of curriculum development that the teacher can and should become involved (Fullan, 2001). And this involvement is more than the activities defined within the classroom walls. Carl (2002) distinguished two main tendencies regarding teacher participation:

- Firstly, teachers are regarded as merely the "recipients" of the curriculum that is developed by specialists elsewhere. The teacher's curriculum function remains limited to the correct application of what has been developed by these specialists. Thisso-called "top down" approach is detrimental to the process of taking ownership of the curriculum.

- Secondly, teachers are partners in the process of curriculum change. There should therefore be an opportunity for their "voices" to be heard before the actual implementation, in other words, they should be given the opportunity to make an input during the initial curriculum development processes.

The educational system often determines which of these two interpretations or tendencies triumphs. For Kirk \& Macdonald (2001), aspects such as leadership and the centralization or decentralization of an educational system, that allows input and participation, may determine or influence the nature and the degree of participation.

\subsection{The Centralization of the Saudi EFL Curriculum}

Saudi educational system is centralized and controlled by the Ministry of Education (Alshumaimeri, 1999). Unfortunately, it is quite obvious that English language teachers have less autonomy and are teaching with certain boundaries (Al-Sadan, 2000). They are given an identical syllabus with guidelines and deadlines that they are required to apply and follow. This discourages the development of teacher-made materials and provides no opportunities for teachers in the involvement of syllabus design (Al-Seghayer, 2011). Furthermore, this deprivation makes teachers perceive this task to be beyond their responsibility and capability.

The Department of Curriculum Developmentin the Ministry Of Education usually undertakes the tasks of developing guides, establishing standards and planning instructional units. This work is usually done by assigning a group of experts whose tasks also include defining objectives, selecting content and producing instructional materials. Al-Hajailan (1999) (as cited in Al-Seghayer, 2011) indicates that the MOE distributes EFL textbooks to elementary, intermediate and secondary students throughout the country to ensure that all students receive similar instructions.

However, in order to improve the curriculum, the MOE relies on teachers' suggestions, supervisors' reports and the contribution of language researchers. Zaid (1993), (as cited in Al-Seghayer, 2011) states that although teachers are encouraged to submit recommendations for improvements to the English curriculum (especially textbooks), many do not take advantage of this option, possibly due to a lack of some professional requirements such as knowledge about English-language curriculum development, planning, design and evaluation.

\subsection{The Professional Requirements of Syllabus Designers}

Other work on teachers as curricular decision-makers focuses on the qualifications and the professional preparation needed. Palmer (1992) reported thatpre-service teachers go through a considerable amount of preparation in structured educational programs, and although there is often a large gap between what happens on 
anin-service course and what subsequently happens in the classroom, yet once they become classroom teachers, they undergo annual evaluations and attend in-service workshops for their continuous professional development. Cohen \& Hills (2001) added that teachers work closely with students and have firsthand knowledge of their strengths and weaknesses. They are in a unique position to recognize students' emotional issues and needs. Yet the question to be asked here, can the insights and experiences of teachers become a meaningful, worthwhile tool in syllabus design?

At the classroom level, the answer will be absolutely yes. Alamri (2008) conducted a study of the Grade 6 English Language textbook. He tried to elicit the perspectives of (93) English teachers and (11) supervisors concerning the book. The results showed a number of serious issues needed to be resolved, such as the fact that the book lacks communicative tasks and activities that cater to different levels of formality and different learning styles, and that it lacks topics that stimulate learners' critical thinking. Furthermore, it employs teaching methods that are outdated and student-centered rather than child-centered. Such findings reveal that teachers can practically participate in syllabus discussions whenever the classroom level is in the frame. In his study, Al-hazmi (2003) supported this tendency by indicating that teachers are professionally prepared to engage in discussions regarding textbook content, the ordering of this content and the planning of activities and assessments.

But in a broader perspective, however, the experiences and the insights of teachers may seem in adequate. Jorgenson (2006) argued that curriculum designers should have not only a comprehensive understanding of the pragmatics of curricular design and instructional practice, but also a global understanding of education as a societal enterprise. They are required, as stated by Kumar (2000), to have more than a general understanding of psychology, but also to consider developmental, cognitive, emotional and communicative factors. Moreover, they must be well versed and articulate inclassic and contemporary educational research, theory, and practical expectations across all subcategories including learning and instructional methodologies. Handler (2010) indicated also that teachers must have strong theoretical bases on which to build, and they must be able to functionally separate the theoretical from the practical as needed. Curriculum decision-making, as stated by Griffin (1990), is a complex task that requires substantial depth and breadth of understanding of the educational enterprise including the relationships and influences that drive policy and practice.

\section{Methodology}

\subsection{Participants}

Ten English language teachers from different governmental schools in Riyadh participated in this study. They represent three instructional levels; secondary level (4 teachers), intermediate level ( 3 teachers) and elementary level ( 3 teachers). The criterion used for selection was based on the number of teaching years, approximately more than ten years, which they had spent with Saudi syllabuses.

\subsection{Instruments and Procedure}

Data was collected using semi-structured interview techniques. It was believed that the data collected by this method would enable the teachers to elaborate on the issue raised allowing the researcher to explore the underlying patterns of thinking. The interview questions are as follows:

a. The general perception of saudi english language teachers:

- Have you ever attended any programs or workshops in which you were taught about syllabus design?

- Have you ever been asked to give any suggestions for improvements in the syllabus you are teaching?

- To what extent you feel that you have been deprived from participation in designing a syllabus for your students?

b. The limitations of teaching english:

- Do you think that an identical syllabus limits the chances for teacher's creativity?

- Do you apply the activities in your textbooks or you prefer to create your own? Why?

- Do you follow the assessment criteria provided by the Ministry of Education or you design your own? Why?

c. The possession of qualifications:

- What are the basic elements of a teaching syllabus?

- If you were asked to participate in designing a syllabus, what is the most convenient type you would 
choose? Why?

- In what criteria you would judge the suitability of a syllabus.

\subsection{Data Analysis}

The data obtained from the interviews was content analyzed. Notes were taken of teachers' answers and were listed in specific descriptive phrases that could be presented and read in a clear and comprehensible fashion. And in order to maintain the truth value of the teachers' comments, the extracts quoted are presented as they are without any editing.

\section{Results and Discussion}

Teachers' comments reveal a deep-seated need for a greater degree of participation and access to the process of decision-making. The core of the responses is that teachers are not afforded the opportunities to participate before hand. They are all of the opinion that decisions are being made on their behalf. They feel that they are only involved in the application and implementation ofthe curriculum. Furthermore, when it comes to assessing students, their passion for more autonomy seems to increase as the regulations of the Saudi educational system omit anyreference to teachers' approaches or views. However, it is also noted that while teachers may perform creativelyin their classroom instruction, yet they do not appear to possess the required qualifications of a leadership role in the curriculum development process. This lack of requisite knowledge is basically due to the fact that no specific and focused education regarding curriculum development and decision-making has been given to them. The following three themes discuss the major findings of the study.

\subsection{The General Perception of Saudi English Language Teachers}

In their responses, teachers make frequent references to the feeling of is olation they have regarding decision-making;

"During my 15 years in teaching English for various levels, I have never been asked to participate in designing a course book or even to evaluate the one I am teaching" (Anelementary school teacher, 15 years of teaching experience).

"I have no say in the syllabus and I am bound by the Ministry to finish the syllabus on time. I can't even change or skip the parts I think that they are not suitable" (An intermediate school teacher, 11 years of teaching experience).

"Even when we give our suggestions they are not taken seriously into consideration" (A secondary school teacher, 12 years of teaching experience).

Such responses cast more light on the central leadership of the Saudi educational system. It is obvious that until recently no opportunities have been created for involving teachers directly in the processof curriculum change at all levels. This is in accordance with what Kirk \& Macdonald (2001) have noted on the impact of aspects such as the centralization of an educational system that may determine or influence the nature and the degree of teacher's participation. Moreover, these findings unambiguously confirm what has been indicated by Al-Seghayer (2011) and Kennedy (1996) regarding teachers' perceptions of syllabus design as a task that is developed elsewhere, a task that is beyond their responsibility and capability.

\subsection{The Limitations of Teaching English}

Since the task of constructing an instructional syllabus is highly controlled by the Ministry of Education, this part of data attempts to detect the degree of freedom, which teachers may enjoy in their classes.

"My supervisor makes regular visits just to check if I'm following the traditional procedures in my written tests" (Asecondary school teacher, 10 years of teaching experience).

"I prefer to create my own activities in class to replace the ones in the book, but I must follow the assessment criteria provided by the Ministry" (A secondary school teacher, 13 years of teaching experience).

"I like to design my own tasks, games and even teaching aidswhich I think they are more useful, interesting and motivating to my students. These are in line with the new learning theories and strategies" (An elementary school teacher, 11 years of teaching experience).

It is obvious that there is an overall agreement that an identical syllabus does not limit the extent to which teachers can foster creativity in their classroom behavior. However, when it comes to assessment, theyare carefully subjected to follow similar procedures and guidelines. These findings mirror those of Al-Sadan (2000) in which teachers have less autonomy and are teaching with certain boundaries. They also assert what has been 
indicated by Al-Hajailan (1999) regarding the frequent instructions which Saudi teachers commonly receive from the Ministry of Education.

\subsection{The Possession of Qualifications}

Having no access in the process of decision-making, the majority of teachers appear to have vague notions of syllabus design. Though they succeeded somehow to mention the basic elements of a teaching syllabus, yet the dilemma the teachers felt was when asked about the types of syllabus and the criteria used for evaluating them;

"I have no idea, but surely I would choose the type that motivates the learners to produce the language" (Asecondary school teacher, 13 years of teaching experience).

"I think young learners want their books to be full of games, pictures and quizzeswhile older ones want more logical things" (An intermediate school teacher, 11 years of teaching experience).

"I am not sure but I think I would choose the one that is up-to-date and suitable to our Saudi life" (An elementary school teacher, 15 years of teaching experience).

Such comments prove that there is a kind of comprehensive deficiency regarding the theoretical bases of curricular design. They also shed more light on what has been often alleged that teachers want only to deal with the practicalities of their work, without the need to be exposed to broader aspects of curriculum theories (Carl, 2002). Hence, they appear to be, as Griffin (1990) argued, unsure and uninformed about the educational policies of curriculum design and the educational practices that are likely to serve those policies and how to effectively organize and evaluate those practices.

\section{Conclusion}

There is no doubt that teachers are valuable resources for the development and implementation of educational policies. However, the regulations and procedures of the Saudi educational system rarely refer to teachers as curriculum designers. The only spheres of freedom are within their classroom practices, where they can often create their own lesson plans, activities and teaching aids. To goeven further beyond, the system works as "a killer of teacher's creativity" regarding assessment, focusing mainly on one objective: how many pupils will pass?

Though creating a curriculum from the ground up takes more resources and experience than most teachers have, yet it is essential that teachers must have a relationship with what they teach, as well as with the people they teach it to. They must interact with both, not just deliver one to the other. The Ministry of Education needs to push for a new, innovative reform in which curriculum is regarded as a dynamic event, not as "a river of experience that courses through student and teacher over the years of school". Seen this way, teachers should be informed and trained in the process of curriculum design. It is essential that they have the depth of knowledge required to fulfill that role effectively. Support for the acquisition of that knowledge must begin in teacher per-service preparation courses and continue through professional in-service development activities. With such support, teachers can effectively share their approaches, materials, and insights. Consequently, their voices would be put inplace for curriculum development so as to enhance productivity and efficacy for the quality education. Indeed, these voices must be heard.

\section{References}

Al-Hazmi, S. (2003). EFL Teacher Preparation Programs in Saudi Arabia: Trends and Challenges. TESOL Quarterly, 37(2), 430-440. http://dx.doi.org/10.2307/3588509

Al-Sadan, A. I. (2000). Educational Assessment in Saudi Arabian Schools. Profile of Educational Assessment Systems Worldwide. Assessment in Education, 7(1). http://dx.doi.org/10.1080/713613320

Al-Seghayer, K. (2011). Teaching English in Saudi Arabia: Status, Issues, and Challenges. Riyadh: Hala Print $\mathrm{CO}$.

AlShumaimeri, Y. A. N. (1999). Saudi Students' Perceptions of Their Textbook: English for Saudi Arabia, (EFSA), Secondary Year One. Master Dissertation. University of Leeds. School of Education. Retrieved from http://faculty.ksu.edu.sa/yousif/default.aspx

Bowers, B. (1991). Teacher Involvement in Curriculum Development. National Association of Elementary School Principles, 7(3). Retrieved from http://eric.ed.gov/?id=ED331153

Carl, E. A. (2002). Teacher Empowerment through Curriculum Development: Theory into Practice. Juta \& Co Ltd.

Cohen, D. K., \& Hills, H. C. (2001). Learning policy: When state education reform works. New Haven, CT: Yale University Press. http://dx.doi.org/10.12987/yale/9780300089479.001.0001 
Doll, R. C. (1996). Curriculum improvement: Decision making and process (9th ed.). Boston: Allyn \& Bacon.

Griffin, G. A. (1990). Curriculum decision making for teacher education. Theory into practice, 29(1), 36-41. http://dx.doi.org/10.1080/00405849009543428

Handler, B. (2010). Teacher as Curriculum Leader: A Consideration of the Appropriateness of that Role Assignment to Classroom-Based Practitioners. International Journal of Teacher Leadership, 3(3). Retrieved from http://www.csupomona.edu/er.pdf

Hecht, E. W. D., Higgerson, M. L., Gmelch, W. H., \& Tucker, A. (1999). The Depar (1999Chair as Academic Leader. Phoenix, AR: American Council on Education Oryx Press.

Jorgenson, O. (2006). Why Curriculum Change Is Difficult and Necessary. National Association of Independent Schools. Retrieved from http://www.nais.org/publications/ismagazinearticle.cfm

Kennedy, Ch. (1996). Teacher Roles in Curriculum Reform. ELTED Journal, 2(1). Retrieved from http://www.elted.net/uploads/7/3/1/6/7316005/v2kennedyc.pdf

Kirk, D., \& Macdonald, D. (2001). Teacher voice and ownership of curriculum change. Journal of Curriculum Studies, 33(5), 551-567. http://dx.doi.org/10.1080/00220270010016874

Klein, M. F. (1999). Whose standards? What curriculum? Kappa Delta Pi Record, 35(2). Retrieved from http://dx.doi.org/10.1080/00228958.1999.10518417

Kumar, D. D. (2000). Opportunities for Teachers as Policy Makers. Kappa Delta Pi Record, 36(2). http://dx.doi.org/10.1080/00228958.2000.10532019

Palmer, Ch. (1992). Innovation and the experienced teacher. ELT Journal, 47(2), 166-171. Retrieved from http://dx.doi.org/10.1093/elt/47.2.166

\section{Appendix}

\section{Dear Teacher:}

In my research (The Role of The Teacher in Syllabus Design), I gratefully value your feedback. Your opinions are completely anonymous. I appreciate your participation!

\section{Teacher Name}

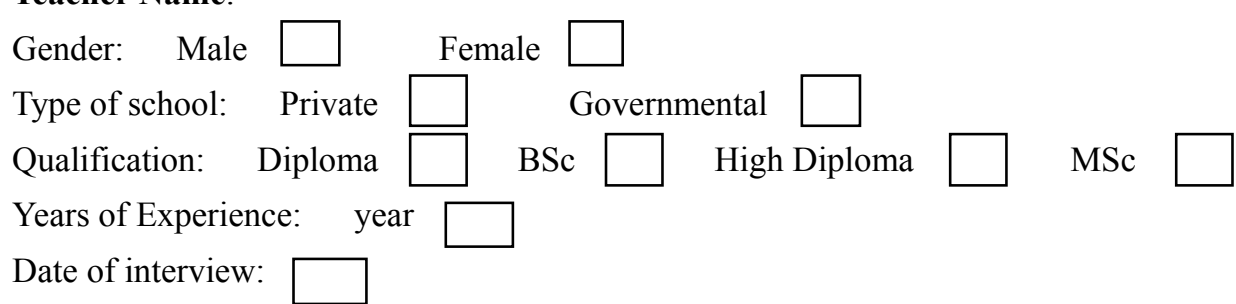

\section{The General Perception of Saudi English Language Teachers:}

Q1: Have you ever attended any programs or workshops in which you were taught about syllabus design?

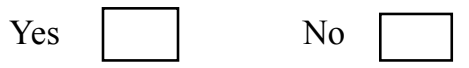

Q2: Have you ever been asked to give any suggestions for improvements in the syllabus you are teaching?

Yes $\square$

No

Q3: To what extent you feel that you have been deprived from participation in designing a syllabus for your students? How?

To large extent

to some extent

\section{The Limitations of Teaching English:}

Q4: Do you think that an identical syllabus limits the chances for teacher's creativity?

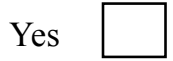

No

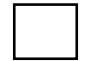

to some extent 
Q5: Do you apply the activities in your textbooks or you prefer to create your own? Why?

Yes $\square$

No

to some extent

Q6: Do you follow the assessment criteria provided by the Ministry of Education or you design your own?Why?

Yes

No

to some extent

\section{The Possession of Qualifications:}

Q7: What are the basic elements of a teaching syllabus?

Q8: If you were asked to participate in designing a syllabus, what is the most convenient type you would choose? Why?

Q9: In what criteria you would judge the suitability of a syllabus?

\section{Thank you for your time.}

\section{Copyrights}

Copyright for this article is retained by the author(s), with first publication rights granted to the journal.

This is an open-access article distributed under the terms and conditions of the Creative Commons Attribution license (http://creativecommons.org/licenses/by/3.0/). 